International Journal of Current Microbiology and Applied Sciences

ISSN: 2319-7706 Volume 10 Number 09 (2021)

Journal homepage: http://www.ijcmas.com

\title{
GIS based Soil Nutrient Assessment of Available Macro and Micronutrients in Tommaladahalli Microwatershed of Chikkamagaluru District, Karnataka, India
}

\author{
M. S. Anitha ${ }^{1 *}$, K. T. Gurumurthy ${ }^{2}$ and Ganapathi ${ }^{3}$ \\ ${ }^{1} S S$ \& AC, Krishi Vigynan Kendra, Tiptur, Tumkur (D), India \\ ${ }^{2}$ University of Agricultural Sciences, Bengaluru, Karnataka, India \\ ${ }^{3}$ Department of SS \& AC, KWDP II, SUJALA III Watershed Project, University of \\ Agricultural and Horticultural Sciences, Shivamogga, Karnataka, India \\ *Corresponding author
}

Keywords

Krigging, GIS, interpolation, micronutrient, Tommaladahalli

Article Info

Accepted: 20 August 2021 Available Online: 10 September 2021
An investigation was undertaken in Tommaladahalli (566.13 ha) microwatershed of Tarikere taluk, Chikkamagaluru district of Karnataka to assess available nutrient status in the surface soils. About 118 surface soil samples were collected grid wise by using cadastral map at $250 \mathrm{~m}$ grid interval and were analyzed for their fertility status using standard procedures. Soil fertility maps were prepared by means of interpolation method called Krigging. The results revealed that the $\mathrm{pH}$, electrical conductivity, and organic carbon were ranged from 5.37 to $9.06,0.065$ to $0.466 \mathrm{dS} \mathrm{m}^{-1}$ and 0.33 to 1.62 per cent respectively. The available $\mathrm{N}, \mathrm{P}_{2} \mathrm{O}_{5}, \mathrm{~K}_{2} \mathrm{O}$ were ranged from 175.6 to $545.6 \mathrm{~kg} \mathrm{ha}^{-1}, 11.8$ to $61.1 \mathrm{~kg} \mathrm{ha}^{-1}$ and 122.7 to $491.4 \mathrm{~kg} \mathrm{ha}^{-1}$, respectively. The available nitrogen and phosphorus were low to medium, where as potassium content was medium to high in the entire study area. Micronutrients viz. zinc, iron and boron were sufficient and were ranged from 0.34 to $1.17 \mathrm{mg} \mathrm{kg}^{-1}, 2.03$ to $21.86 \mathrm{mg} \mathrm{kg}^{-1}$ and 0.30 to $0.89 \mathrm{mg} \mathrm{kg}^{-1}$ respectively.

\section{Introduction}

Increasing population pressure and overexploitation of productive lands leads to serious problem of lowering the fertility status of soil. The deficiency of nutrients directly affects on the crop growth and response. The availability of nitrogen, phosphorus and potassium (NPK) in soils is among most of the nutrient studied for precision agriculture. Soil testing plays an important role in the use of fertilizers and other agricultural inputs. Soil 
test summaries and soil fertility maps are of vital necessity as reference materials for scientific management of soil. This information will also help to adopt effective strategy on fertilizer use and cropping pattern. soil nutrient based fertilizer recommendations should be preferred to achieve precision in farming and to maximize crop production, maintain soil health and minimize fertilizer misapplication (Ramamurthy et al., 2009). Hence it is necessary to assess the fertility status of soil with the consideration of available nutrients in soils and to recommend the specific nutrients for the proper management of soil. Information on soil fertility status in crop field is very important and useful for fertilizer requirement and also to the specific management of the crop and soil. With this back ground the present investigation was taken up to study nutrient status and mapping using GIS for the entire watershed.

\section{Materials and Methods}

\section{Study area}

The study area of Tommaladahalli micro watershed is located in Chikkamagaluru district of Karnataka state. The watershed area lies between $13^{\circ} 46^{\prime} 36^{\prime \prime} \mathrm{N}$ latitude and $76^{\circ} 0^{\prime}$ $11^{\prime \prime}$ E longitude with a spatial extent of 566.13 ha. The study area comprises of five villages viz. Abbinaholalu, Muguli, Beguru, Asandi, Katiganere and Karihalli. Location map is given in Fig.1. The average temperature ranges from $16^{\circ} \mathrm{C}$ in winter months of December, January and February to $36^{\circ} \mathrm{C}$ during summer months of March, April and May. The mean annual rainfall for the last three decades in study area is $600 \mathrm{~mm}$. The region receives rainfall mainly from SouthWest monsoon and partly from North East monsoon with an annual rainfall season spreading over a period of 4 to 5 months. The South-West monsoon occurs from June to
September amounting to about 68 per cent and North East monsoon during October to November contributing about 32 per cent of the rainfall. Average relative humidity is about 65 per cent.

\section{Sampling}

Spatial locations of all sampling points of Tommaladahalli were acquired using portable GPS (Global Positioning System) equipment.

About, 118 surface soil samples were collected at a depth of $15 \mathrm{~cm}$ from different locations at a grid interval of $250 \mathrm{~m}$ during the same period. Collected soil samples were airdried after removing stones and coarse plant roots or residues. Samples were thoroughly mixed and ground to pass through a $2.0 \mathrm{~mm}$ sieve, then stored in plastic bags prior to physical and chemical analysis.

\section{Analysis}

Sieved soil samples were determined for $\mathrm{pH}$ and electrical conductivity at 1:2.5 soil water suspensions (Jackson 1973). Organic carbon was measured by Chromic acid wet digestion method (Walkley and Black 1934). The available $\mathrm{Zn}, \mathrm{Cu}, \mathrm{Mn}$, and Fe contents were assessed by extracting $10 \mathrm{~g}$ of each soil with $20 \mathrm{ml}$ of diethylenetriamine penta-acetic acid extractant (0.005 M DTPA + 0.01 $\mathrm{M} \mathrm{CaCl} 2+$ $0.1 \mathrm{M}$ triethanolamine), adjusted to $\mathrm{pH} 7.30$ (Lindasy and Norwell, 1978). Determinations were performed on the same extract with an Atomic Abosorption Spectrometer. Boron content in soil samples were extracted by hot water method and determined by the Azomethine-H reagent method (Keren 1996). The mapping of soil properties such as $\mathrm{pH}$, $\mathrm{EC}, \mathrm{OC}$, and micronutrients were prepared by means of interpolation method of Kriging. Soil test values at unsampled locations were interpolated using geostatistical technique of kriging (Trangmar et al., 1985). 


\section{Results and Discussion}

The soil reaction in the study area was slightly acidic to alkaline (5.37 to 9.06). The high $\mathrm{pH}$ of the soils might be due to the presence of high degree of base saturation as reported by Meena et al., (2006). Out of 566.13 ha, 188 ha was under moderately alkaline condition (33.16\%), 182 ha under strongly alkaline condition $(32.15 \%)$ and rest was in neutral to slightly alkaline range (Table 1). The extent of different classes of soil reaction is presented in Fig. 1.

The EC values in watershed area ranged from 0.06 to $0.47 \mathrm{dS} \mathrm{m}^{-1}$ indicating that the soils of selected micro watershed were non saline in nature. About 99.73 per cent area covered under normal (non saline) range.

This may be due to undulating nature of the terrain coupled with fairly good drainage conditions, which favored the removal of released bases by the percolating drainage water (Shivaprasad et al., 1998). These soils did not show any specific relationship with depth. These results were in confirmation with the findings of Kumar (2011).Organic carbon content of these surface soil samples was found low to high and ranged from 0.33 to 1.62 per cent (Fig. 2).

About 120 ha area of the micro watershed was under medium category (21.29\%) and 428 ha area was under high category (75.58 \%). According to Rao et al., (2008) higher clay content in black soil was responsible for higher organic carbon content.

The available phosphorus content in the study area ranged from 11.8 to $61.1 \mathrm{~kg}$ per ha (Fig.3). The low values of available phosphorus which may be due to low CEC, clay content and soil reaction of $<6.5$, Ravikumar et al., (2019). The available potassium content in major portion of the study area was under medium to high category (Fig. 4) and it was ranged from 122.7 to 491.4 $\mathrm{kg} \mathrm{ha}^{-1}$, the higher content of potassium might be due to the predominance of potash rich micaceous and feldspar minerals in parent rocks (Dasog and Patil, 2011).

About 416 ha and 148 ha area occupying 73.58 per cent and 26.14 per cent of study area were medium and high inavailable potassium respectively (Fig. 4).

The available iron content in micro-watershed ranged from 2.03 to $21.86 \mathrm{mg} \mathrm{kg}^{-1}$. About 446 ha $(78.84 \%)$ of the study area were sufficient in range while 118 ha $(20.88 \%)$ had deficient in available iron status of study area (Fig.5). The available iron content was higher in the study area.

This may be due to the granite gneiss parent material which is known to possess higher iron content. The available manganese content in micro- watershed ranged from 1.82 to 18.43 $\mathrm{mg} \mathrm{kg}^{-1}$ and was sufficient in range. The higher available manganese content in these soils attributed to its higher content in granite genesis parent material. (Rajkumar 1994).

The available zinc content of micro watershed area ranged from 0.34 to $1.17 \mathrm{mg} \mathrm{kg}^{-1}$. About 316 ha $(55.86 \%)$ of the study area were sufficient in range while 248 ha $(43.86 \%)$ had deficient in available zinc status of study area (Fig. 6).

The overall higher copper content in the micro watershed area was due to the parent material (Rajkumar 1994). Major samples of the microwatershed area fall under low to medium category for available Boron. About 446 ha of study area falls under medium category and 118 ha coming under high category of boron class. 
Table.1 Extent of spatial variability in different classes of soil properties in the study area

\begin{tabular}{|c|c|c|c|c|c|}
\hline Sl. No. & Soil properties & Classes & Range of & Area & Area $(\%)$ \\
\hline \multirow[t]{3}{*}{1} & \multirow[t]{3}{*}{$\mathrm{pH}$} & Slightly acidic to moderately & $6.5-5.5$ & 48 & 8.6 \\
\hline & & Neutral & $6.5-7.3$ & 69 & 12.24 \\
\hline & & Slightly alkaline to very & $7.3->9.0$ & 447 & 78.89 \\
\hline 2 & $\mathrm{EC}(\mathrm{dSm}-1)$ & Non saline & $<02$ & 564 & 99.73 \\
\hline \multirow[t]{3}{*}{3} & \multirow{3}{*}{$\begin{array}{c}\text { Organic } \\
\text { Carbon (\%) }\end{array}$} & Low & $<0.5$ & 16 & 2.9 \\
\hline & & Medium & $0.5-0.75$ & 120 & 21.3 \\
\hline & & High & $>0.75$ & 428 & 75.6 \\
\hline \multirow[t]{2}{*}{4} & \multirow{2}{*}{$\begin{array}{c}\text { Phosphorus } \\
\text { (Kg/ha) }\end{array}$} & Low & $<23$ & 371 & 65.5 \\
\hline & & Medium & $23-56$ & 193 & 34 \\
\hline \multirow[t]{2}{*}{5} & \multirow{2}{*}{$\begin{array}{l}\text { Potassium } \\
(\mathrm{Kg} / \mathrm{ha})\end{array}$} & Medium & $140-330$ & 416 & 73.6 \\
\hline & & High & $>330$ & 148 & 26.1 \\
\hline \multirow[t]{2}{*}{6} & \multirow[t]{2}{*}{ Iron (ppm) } & Sufficient & $>4.5$ & 446 & 78.8 \\
\hline & & Deficient & $<4.5$ & 118 & 20.9 \\
\hline 5 & Manganese & Sufficient & $>1.0$ & 564 & 99.7 \\
\hline \multirow[t]{2}{*}{6} & \multirow[t]{2}{*}{ Zinc (ppm) } & Deficient & $<0.6$ & 248 & 43.9 \\
\hline & & Sufficient & $>0.6$ & 316 & 55.9 \\
\hline \multirow[t]{2}{*}{7} & \multirow[t]{2}{*}{ Boron (ppm) } & Medium & $0.5-1.0$ & 446 & 78.9 \\
\hline & & Low & $<0.5$ & 118 & 20.8 \\
\hline
\end{tabular}

Fig.1 Soil reaction map of Tommaladahalli

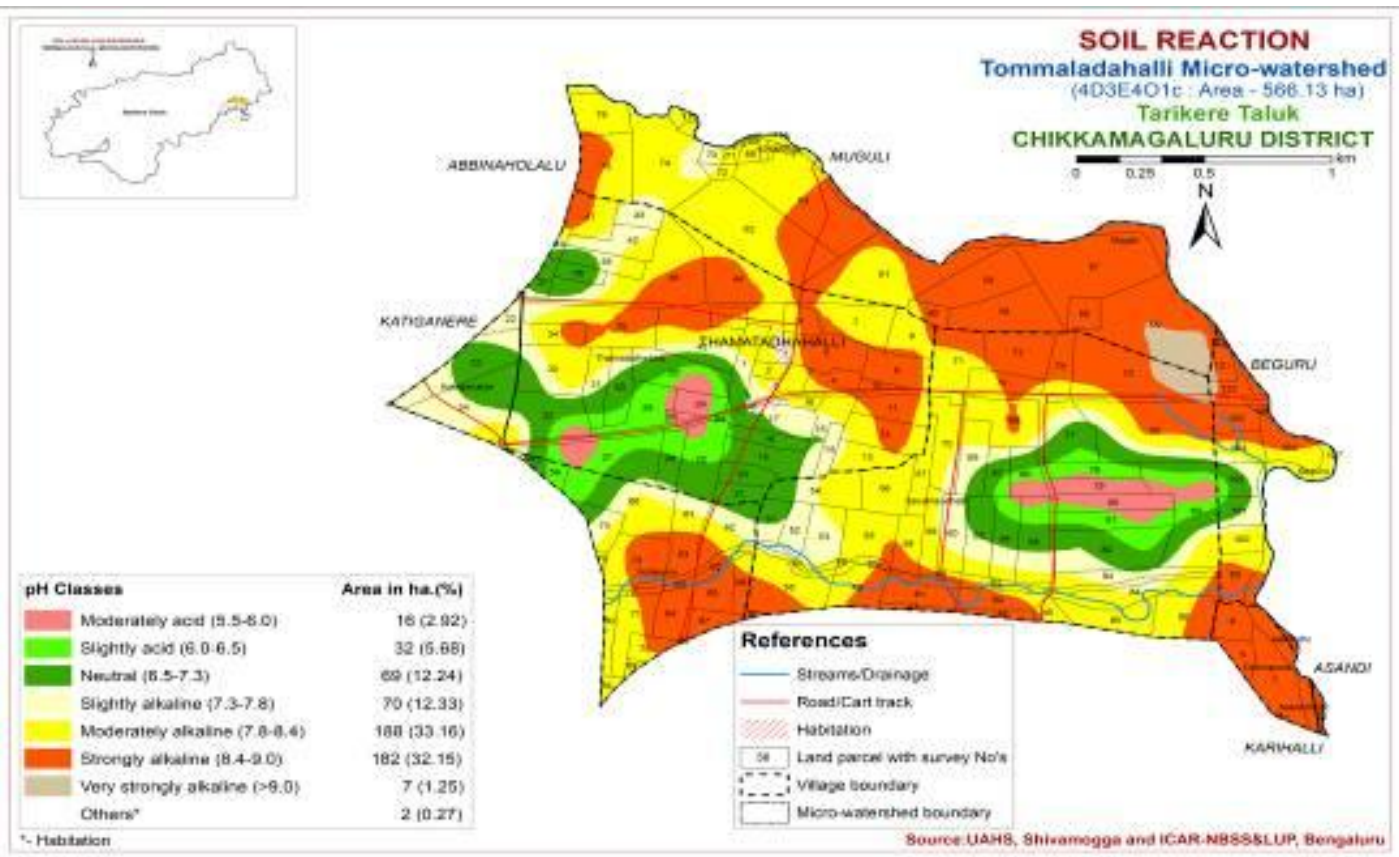


Fig.2 Organic carbon map of Tommaladahalli

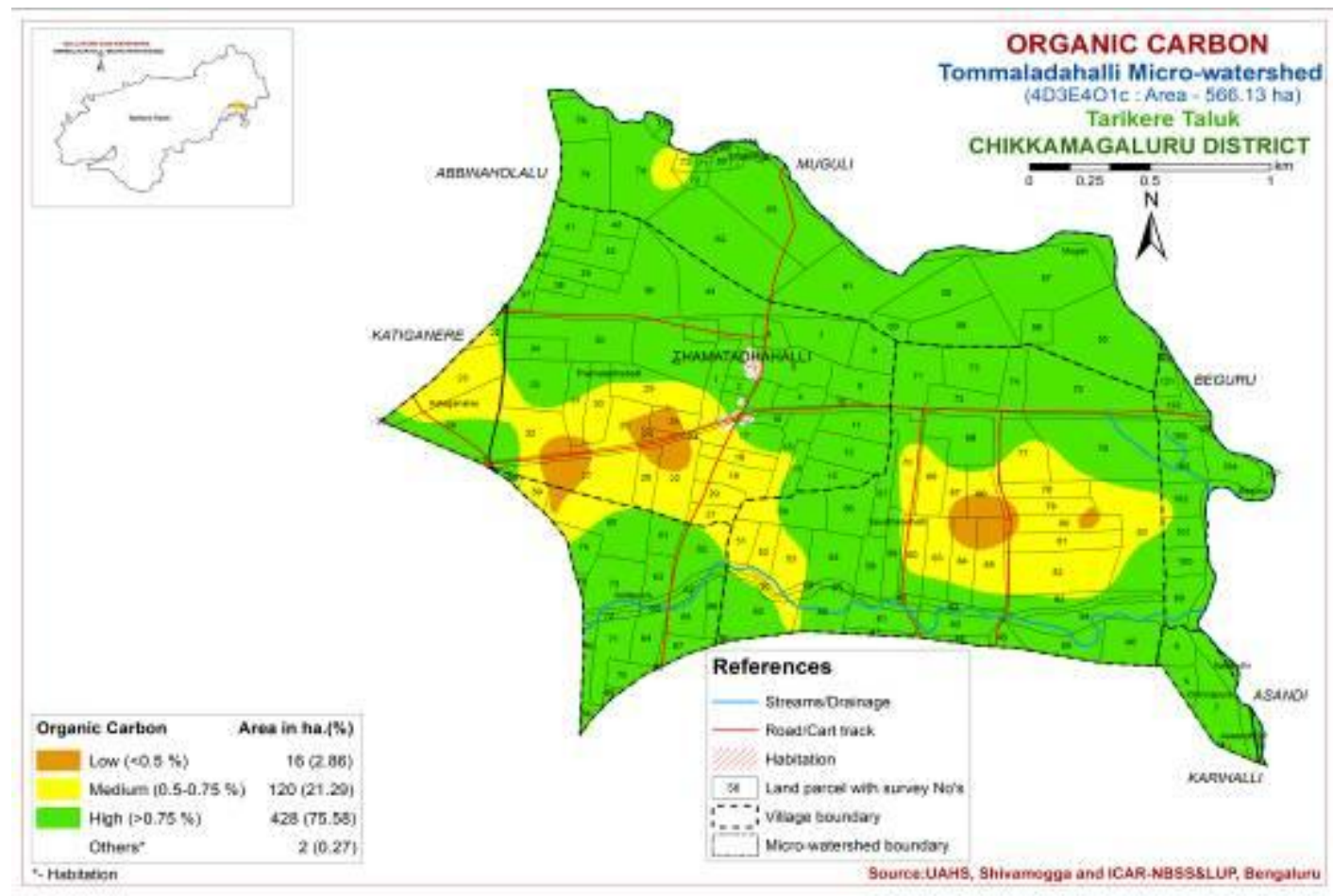

Fig.3 Available phosphorus map of Tommaladahalli

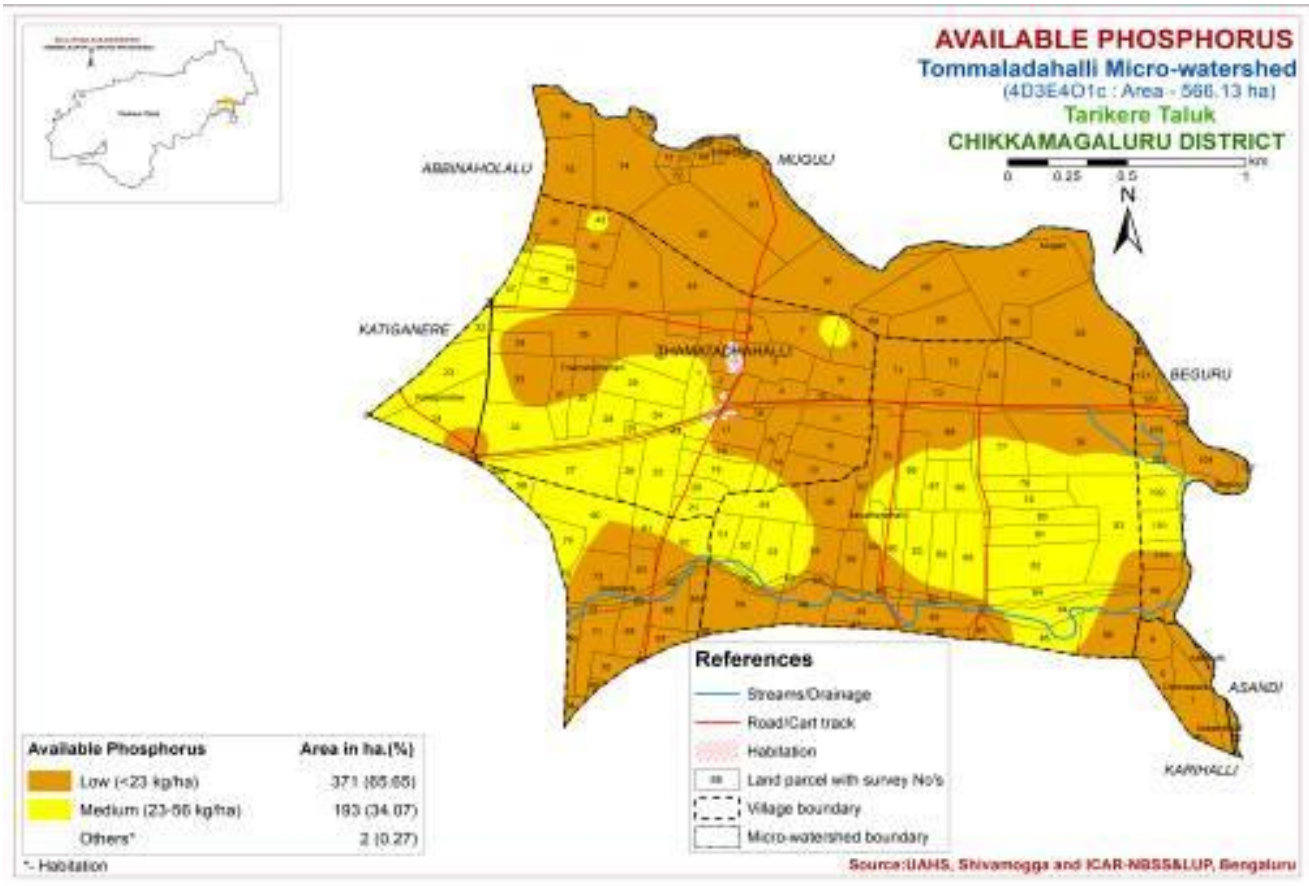


Fig.4 Available potassium map of Tommaladahalli

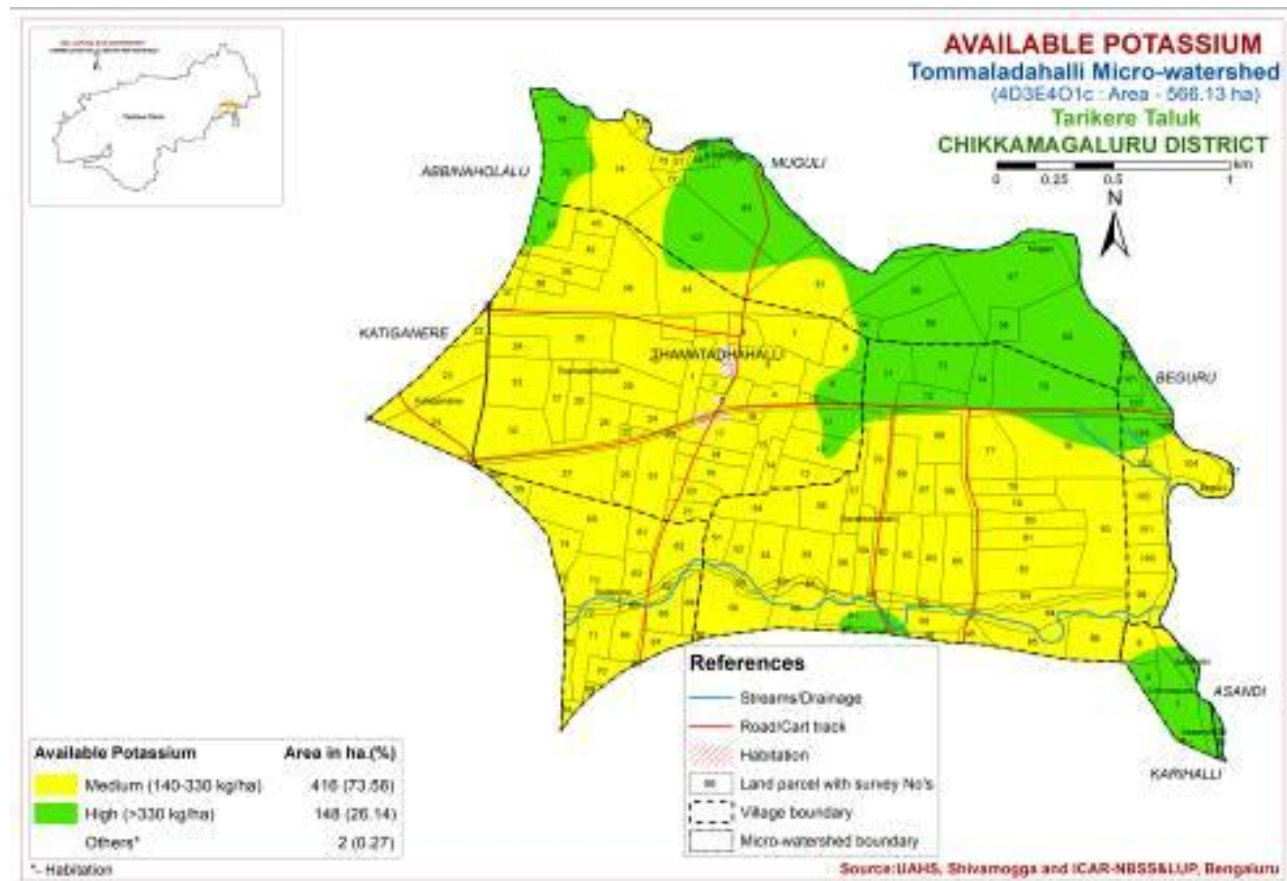

Fig.5 Available iron map of Tommaladahalli

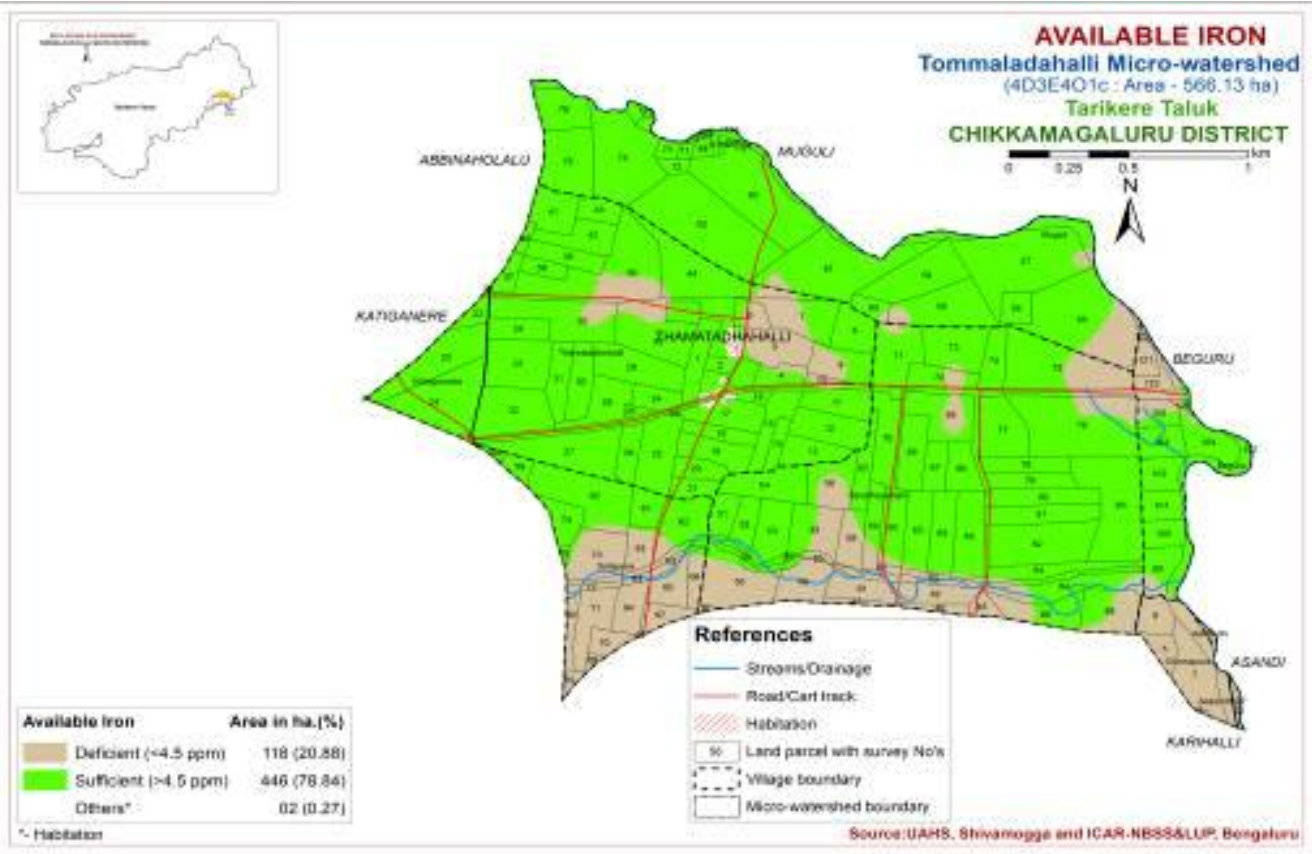


Fig.6 Available iron map of Tommaladahalli

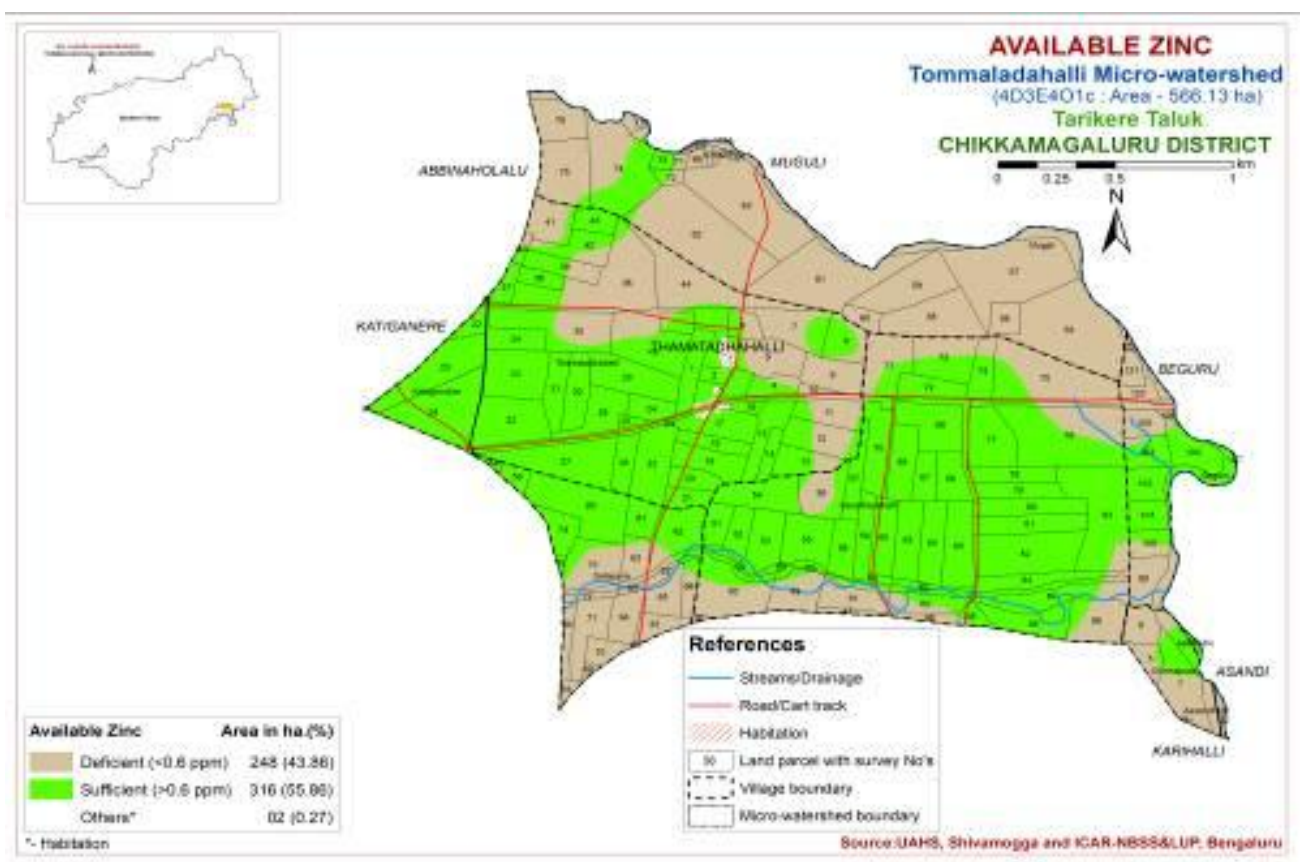

Soil $\mathrm{pH}$ ranged from neutral to alkaline in reaction (5.37 to 9.06). Salt content was very low indicates soils are non-saline in nature and organic carbon content was low to high $(0.33$ to $1.62 \%$ ), Available phosphorus content were low to medium (11.8 to $\left.61.1 \mathrm{~kg} \mathrm{ha}^{-1}\right)$. These variations of phosphorus in soils are may be due to variation in soil properties like clay content, CEC and P fixation capacity. Available micronutrients such as zinc and iron are deficient but copper and manganese were sufficient in these soils of micro-watershed.

\section{Acknowledgement}

This research is supported by World Bank funded KWDP II, Sujala III project, Government of Karnataka. The authors are grateful for providing financial and technical assistance.

\section{References}

Dasog G S, Patil P L., 2011, Genesis and classification of black, red and lateritic soils of Karnataka. Soil Science
Research in North Karnataka, Dharwad chapter of ISSS (Ed.), 76 th annual convention of ISSS., 1-10.

Jackson M L, 1973, Soil Chemical Analysis. Oxford \& IBH Publishing Co., Bombay.

Keren, R. and Bingham, F. T., 1985, Boron in water, soils and plants. Adv. Soil. sci., 229-216

Kumar M D., 2011, Characterization and classification of soils of a microwatershed on basalt parent rock in Northern transition zone of Karnataka. M. Sc. (Agri.) Thesis, University of Agricultural Sciences, Dharwad, Karnataka.

Lindsay, W. L and Norwell, W. A., 1978, Development of a DTPA test for zinc, iron, manganese and copper. Soil Sci.Soc. Am. J., 42,421-428.

Meena H B, Sharma R S, Rawat R S. 2006, Status of Macro and Micronutrients in some soils of Tonk district of Rajasthan. J. Ind. Soc. Soil Sci. 54(4):508-512.

Rajkumar, G. R., 1994, Studies on forms and 
distribution of micronutrients in paddy soils of Tungabhadra project area, Karnataka. M. Sc. (Agri.) Thesis Univ. Agric. Sci., Dharwad.

Rao, A. P. V. P., Naidu, M. V. S, Ramavatharam N. and Rao, G. R., 2008, Characterization, classification and evaluation of soils on different landforms in Ramachandrapuram mandal and Chittoor district in Andhra Pradesh and sustainable land use planning. J. Ind. Soc. Soil Sci., 56(1): 23-33.

Ramamurthy V., Naidu L. G. K., Ramesh Kumar S. C., Srinivas S. and Rajendra Hegde, 2009, Soil-based fertilizer recommendations for precision farming. Curr. Sci. 97(5): 641-647.

Ravi Kumar, D. Balaji Naik, K. T. Gurumurthy, Ganapathi, A. N. Raghu, B. C. Dhanjaya, H. S. Sindhu and Anantakumar Patil., 2019, Soil Fertility Status of Available Micronutrients and Mapping in Begaluru Microwatershed of Tarikere
Taluk of Chikkmagaluru District, Karnataka, India. International Journal of Current Microbiology and Applied Sciences . 9 : 230-235.

Sharma, Y. K., and Gangwar, G. S., 1997. Distribution of different forms of sulphur and their relationship with some soil properties in Alfisols, Inceptisols and Mollisols of Moradabad District, Uttar Pradesh. J. Ind. Soc. Soil Sci., 45:332- 335.

Shivaprasad, C. R., Reddy, R. S., Seghal, J. and Velayutaam, M., 1998. Soils of Karnataka for optimizing land use. NBPS \& LUP, Nagpur, 47 p. 15.

Trangmar, B. B., Yost R. S. and Uehara G., 1985, Application of geostatistics to spatial studies of soil properties. Advances in Agronomy, 38: 45-94.

Walkely A. J. and Black, C. A., 1934, An estimation of Deglgare method for determining soil organic matter and a proposed modification of the chromic acid titration method. Soil Sci., 37: 2938.

\section{How to cite this article:}

Anitha, M. S., K. T. Gurumurthy and Ganapathi. 2021. GIS based Soil Nutrient Assessment of Available Macro and Micronutrients in Tommaladahalli Microwatershed of Chikkamagaluru District, Karnataka, India. Int.J.Curr.Microbiol.App.Sci. 10(09): 510-517. doi: https://doi.org/10.20546/ijcmas.2021.1009.059 